\title{
Reinventing Subjectivity: China Miéville's Un Lun Dun and the Child Reader
}

JOE SUTLIFF SANDERS

\begin{abstract}
Miéville's first novel for young readers was an instant success with scholars of children's literature. Its violation of bourgeois models of subjectivity fit nicely with the current discourse about leftist literature and its ability to correct some of the most persistent problems of manipulation and moralism in children's literature. The novel ingenuously fulfills many of the calls to action by scholars, but it also exceeds those calls by imagining a subjectivity for language and books themselves. The result is both a model of readers who avoid complacency and a kind of language against which readers can and must argue.
\end{abstract}

The first novel for young readers by the unapologetically Marxist China Miéville could not have come at a more suitable time for scholars in the field of children's literature, who have recently expressed a resurgent interest in leftist writing for children. In fact at the 2008 meeting of the national Children's Literature Association, two papers focused on Miéville's 2006 novel Un Lun Dun even as preparations were being made to give the association's award for book-length scholarship to Julia L. Mickenberg for her study Learning from the Left: Children's Literature, the Cold War, and Radical Politics in the United States (also published in 2006). Leftism, understood not just as a perspective from which to view children's literature but as a cluster of ideologies from which that literature can be written, is a topic of high interest, and so it should

Extrapolation, Vol. 50, No. 2 (C) 2009 by The University of Texas at Brownsville and Texas Southmost College 
come as no surprise that the name of Miéville's novel was on many lips at the conference both during and between paper sessions.

In this article, I will focus on how Un Lun Dun fits into and in some cases exceeds the expectations for leftist children's literature ${ }^{1}$ within this field of scholarship. To do so, I will first sketch out the project of leftist children's literature as anticipated by the scholarship, the reason this project appeals to contemporary scholars, and how it fills a need that has been woven into the history of the field. This survey will reveal how children's literature scholars tend to privilege readerly discomfort and critical thinking in leftist literature, two things that leftist aesthetic philosophy in general and Miéville in particular are happy to encourage. But Un Lun Dun, I will argue, goes a step further. Not only does Miéville's novel discourage comfortable, passive reading, but it also provides a new set of unsettling subjectivities that encourage the kind of active, critical reading children's literature scholars prize.

\section{Why Children's Literature Longs For The Left}

It is first important to understand why a leftist agenda is important to the project of contemporary scholarship on children's literature. A delight in the proclivities of leftist literature is not a temporal anomaly, but the result of a clear history of a field trying to distance itself from a certain mode of children's literature.

When children's literature scholars such as Mickenberg recapture a history of leftist children's literature, they center their definition of such work on a fairly clear set of terms. In her introduction, Mickenberg notes the difficulty of pinning down a definition of a group of writers and activists with a wide range of left-of-center affiliations but goes on to emphasize that these writers have tended to want to "make children autonomous, critical thinkers who questioned authority and believed in social justice" (11). These sentiments are echoed in her 2008 anthology of leftist children's literature, co-edited with Philip Nel, in which the editors say that "twentieth-century leftists of various stripes used literature to encourage [children] to question the authority of those in power" (1). In his foreword to that volume, Jack Zipes agrees, celebrating "works that contain radical critiques, enabling children to think for themselves" and promising that "radical children's literature. . . will certainly challenge [children] to think critically and creatively about their choices" (ix). For Zipes and others, "critical" can mean both "intellectually engaged" and "inclined toward antagonist readings," leaving some wiggle room in this definition, but Zipes states implicitly what Mickenberg and Nel state explicitly: when children's literature scholars look to the left, they imagine a hegemonic power and a literature that 
will critique it. Thus, literature that encourages children to think for themselves and argue with authority comes to be identified as leftist.

That such a literature would be cherished by scholars of children's literature makes sense in the context of longer trends in this field. As I have outlined elsewhere, ${ }^{2}$ children's literature scholarship by critics such as Geoff Moss (1990), Ann Grieve (1998), and Virginie Douglas (2004) has complained about what Grieve calls "stable, knowable, readable texts which set out comfortably to seduce the child reader" (5). Recent children's literature scholarship distrusts fiction that offers its readers too comfortable a position from which to enjoy the narrative; this is the reason that interest in leftist writings for children has swelled so quickly. The active, critical reader embraced by leftist children's literature is exactly the opposite of the comfortable, seduced reader Grieve decries. But a novel has very little control over what kind of child reads it, so what scholarship on this sort of literature tends to emphasize is how a book can provide an engaging experience - so the child keeps reading - that is simultaneously unsettling. For Grieve, children's novels such as The Westing Game (1978) make readers "uncomfortably aware" of their relationship with the author, prompting an active, "constructive" reading in order "to activate the work" (9), one way of many that a book can embody a level of discomfort that precludes passive reading. This discomfort provides the jolt out of passive consumption that the scholarship identifies with un-critical engagement with literature. It is easy to see how a field that prizes this kind of discomfort would also be inclined to admire the provocative agenda of leftist children's literature.

The roots of this inclination can be seen if we go even further into the history of children's literature. The field of children's literature scholarship is particularly anxious about the issue of uncritical engagement because the history of children's literature has been dominated by books, writers, publishers, reviewers, and educators who have seen the primary purpose of children's literature to be conservative moral indoctrination that requires compliant children. When Zipes praises radical literature for children for encouraging readers to challenge authority, he places that achievement against the backdrop of another, more common literature for children:

To become literate did not mean simply to develop the ability to read; literacy entailed (and still does) a learning process that produced responsible citizens who functioned in a hierarchical society according to its rules. To become literate involved learning to read the world according to letters and words that were to govern one's beliefs and views and that were regulated according to specific guidelines and norms established by the church and state. Children's literature always carried with it a social code that was part of the civilizing process. (vii) 
For Zipes and others, the history of children's literature is marked by a tendency for the manipulative, a tendency for coercive moralism that served the adults writing the literature better than it served the children reading it, and of course it has served even better the power structure built by these adults to maintain the status quo.

If we follow that assumption underlying Zipes's comments, his assumption about the coercive nature of literacy, we can delve even further into ideological basis for the scholarship's recent embrace of leftist children's literature. Consider again Grieve's article, in which she makes a comment similar to that of Zipes. Here, she complains that "Children's books also have a strong ideological function and, historically, exert social control, functioning as part of an educational apparatus - a means of teaching and influencing children" (5). In her use of the term "apparatus," Grieves is alluding to the Althusserian concept of an ideological apparatus, the system by which the state exercises control over its subjects in order to reproduce itself. The educational system, as an ideological apparatus, for example, ensures that the workers necessary to the middle and working classes are produced with the same regularity that, say, the raw wood necessary for the paper industry is produced. Through various apparatuses, the ideology of the economic system - to oversimplify: that workers must be timely and humble, that managers are entitled to a larger share of wealth but exist to execute the wishes of the owners, that theft is wrong - penetrates the being of the subject in a capitalist society. Althusser's tone, which is echoed in Zipes's and Grieve's comments above, is decidedly pessimistic as he describes the closed-circuit loop of a system that replenishes itself by coercing successive generations in the same way. Althusser calls the educational system crucial to keeping capitalism afloat, and, considering that "no other ideological State apparatus has the obligatory (and not least, free) audience of the totality of the children in the capitalist social formation, eight hours a day for five or six days out of seven" (Althusser 156), it is a system uniquely well designed to cross every section of society and ensure future harvests of managers and workers.

Children's literature is a key piece of this apparatus. In recent decades, literature has risen to popularity in the grade school classroom on the back of the argument that the reading of literature-specifically as opposed to textbooks - fosters literacy. Because children's literature has assured itself a place in the educational system through its promise to develop literacy - a profoundly important skill for future laborers as well as managers - children's literature can be another tool in the production of workers ideally and ideologically suited to fill their roles in capitalist society. Althusser's observations about the ideological state apparatus known as the educational system are certainly applicable in our day to children's literature if only because children's 
literature has a place in the apparatus of compulsory education. And children's literature scholars, as Grieve's comment about the "educational apparatus" demonstrates, are aware of this role that the literature we champion can play in the maintenance of the status quo.

While I am on this point, I would like to expand upon the rather dire prophecies Althusser makes and how they have even more coercive implications for children's literature. In addition to providing a key tool for the production of new workers and managers, the writing and reading of literature is key to the production of subjectivity, of the young reader's sense not just of how a good society works, but her or his sense of being a subject within that larger structure. Toward the end of his influential essay, Althusser says,

In this preliminary remark and these concrete illustrations, I only wish to point out that you and I are always already subjects, and as such constantly practice the rituals of ideological recognition, which guarantee for us that we are indeed concrete, individual, distinguishable and (naturally) irreplaceable subjects. The writing I am currently executing and the reading you are currently performing are also in this respect rituals of ideological recognition. (172-73)

For Althusser, literature is a site in which one can realize one's subjectivity, and it is significant that the form of subjectivity recognized in the act of reading - "concrete, individual, distinguishable and (naturally) irreplaceable"sounds suspiciously similar to the "stable, knowable, readable texts which set out comfortably to seduce the child reader" which Grieve critiques (5). Althusser is talking about readers and Grieve about books, but according to Althusser there is an easy slippage from reading books to the subjectivity one confirms by reading them. Althusser demonstrates that subjectivity is recognized in a host of ways - one of which we will explore in more detail below — but, most pertinent for the field of children's literature, Althusser implies that reading is such an effective tool for dictating to a new reader not only what the rules governing good workers and managers will be, but also one's very sense of self. Children's literature scholars, therefore, have had to face the possibility that the field supports a literature that maintains an oppressive status quo.

Moreover, notice that for Althusser these positions are not just places from which ideology can be produced or imbibed; they are themselves part of the ideology. The reader's subjectivity within the current ideological paradigm and the reader's identification as someone who absorbs a text are at least complementary, perhaps even identical, identities. Readership produces subjectivity $^{3}$ and, given the role the acquisition of literacy plays in that most crucial of ideological apparatuses, might even be the identity through which one's understanding of one's position in ideology is obtained: as Marx puts it, 
"Production thus not only creates an object for the subject, but also a subject for the object." Such a relationship between books and readers makes sense. Ideology requires a material foundation in Marxist theory, a point Althusser borrows and expands when he explains the role of education; books could well be the specific material component that supports the ideology of the position of workers and managers. ${ }^{4}$ Further, the positions of passivity and consumption that characterize the role of so many citizens in a consumer society are certainly adumbrated in the relationship between reader and engaging text.

What I have been demonstrating thus far is what children's literature scholarship wants from leftist literature. The discourse has roots in didactic, moralistic, manipulative texts, and it has branches that directly or indirectly support an educational agenda that is profoundly coercive. When children's literature scholarship praises a book such as Miéville's novel, then, it is very likely hoping for a leftist text that will provide the antidote to the closed circuit of which Althusser has warned. ${ }^{5}$

\section{What The Left Can Offer}

What could leftist literature provide that will counteract the manipulative effects of traditional children's literature and the ability of reading itself to determine subjectivity? A hint can be found in Zipes's foreword to Mickenberg and Nel's anthology of radical writings for children. Their book, he warns, "is bound to be both enlightening and disturbing because it touches on the traumatic. It brings forth uncomfortable moments in American cultural history and challenges us to reconsider what we mean when we think and speak about children's literature" (vii). The traumatic encounter with the text is for Zipes intrinsically connected to its potential to enlighten. The ability better to "think and speak about children's literature" is, he implies, girded by the "uncomfortable moments" the book will expose. The goals of leftist literature, in other words, are affected by its penchant for unsettling the reader. Such a conception of the reader's relationship with texts is clearly in keeping with Marxist philosophy. In Terry Eagleton's brief book on Marxism and Literary Criticism, he addresses Bertolt Brecht's anti-bourgeois aesthetic, in which a play "presents itself as discontinuous, open-ended, internally contradictory, encouraging in the audience a 'complex seeing' which is alert to several conflicting possibilities at any particular point" (65). In order to reach this position, Brecht's plays utilize "alienation effects," a term with important implications for our study of readers and their positions:

The result of these "alienation effects" is, precisely, to "alienate" the audience from the performance, to prevent it from emotionally identifying with the play in a way 
which paralyses its powers of critical judgement. The "alienation effect" shows up familiar experience in an unfamiliar light, forcing the audience to question attitudes and behaviour which it has taken as "natural." It is the reverse of the bourgeois theatre, which "naturalizes" the most unfamiliar events, processing them for the audience's undisturbed consumption. In so far as the audience is made to pass judgements on the performance and the actions it embodies, it becomes an expert collaborator in an open-ended practice, rather than the consumer of a finished object. (Eagleton Marxism 64)

Eagleton's observations about Brecht are echoed elsewhere in Marxist criticism, including that written by Miéville himself. In his introduction to a special issue of Historical Materialism, Miéville argues that the "putatively 'realistic' novel about the bickerings of middle-class families that seem hermetically sealed off from wider conflicts" is in fact more escapist-because it is comforting and familiar - than fantasy novels that do engage with political issues ("Symposium" 42). It is that lack of engagement required of a reader in this position that bothers Marxist critics and, as we have seen, children's literature scholars. Thus, Colin McCabe can borrow from Jameson to argue that "It is the cinema's ability to place the spectator in the position of a unified subject that ensures the contradiction between his working activity which is productive and the leisure activity in which he is constantly placed as consumer" (54), and Eagleton can characterize literature as the instrument which "would communicate to [the masses] the moral riches of bourgeois civilization, impress upon them a reverence for middle-class achievements, and, since reading is an essentially solitary, contemplative activity, curb in them any disruptive tendency to collective political action" (Literary Theory 22).

Miéville has famously criticized what he sees as the Tolkienian emphasis on "consolation" in fantasy. In one interview, he says that "the best fantasy is about the rejection of consolation" ("Messing" 5). Recently, he has said that "in much fantastic fiction, especially YA, there are certain structural assumptions about the shape of narrative and the nature of characterization which have always bothered me, so [Un Lun Dun] tries to interrogate some of them" ("Fabular" 9). In the next section, I will explore how Miéville achieves this goal in his novel, how he hopes to reinvent "the modes, rather than merely the contents, of artistic production" (Eagleton, Marxism 67). ${ }^{6}$

\section{Distrusting The Book}

Central to the novel's leftist project of unsettling the reader is targeting the "reverence" with which, Eagleton has argued, literature has traditionally asked its readers to perceive it. The conventional quiet authority of books is not permitted in Un Lun Dun. One book in particular plays an enormous role 
in the culture of the city and plot of the novel. The unnamed book is a sentient, talking being with limited capabilities of movement, and it is surrounded by a band of learned "Propheseers" who disseminate its knowledge to the citizens of Unlondon. In the novel's first section, Miéville presents the reader with the traditional, comforting vision. The book's authority has never been challenged; further, its cryptic descriptions of a hero who will come to defeat the dreaded Smog lay out a narrative for a rescuer in whom the residents of Unlondon can trust. The Propheseers have been preparing for the arrival of Zanna, a girl from London, and they are able to recite the coming triumphs and tribulations of this prophesied heroine, whose appearance and actions are all of course anticipated by the authoritative words of the book of prophecy.

The most important way in which Miéville undermines the reverence with which readers have viewed literature is through the total failure of this prophecy of Zanna as hero. The first major plot twist is Zanna's ignominious defeat in her very first battle: in a two-line paragraph, Zanna falls victim to a "smack," as though the "Chosen One" does not even rate a more heroic bit of onomatopoeia (103). The Propheseers are distraught, and one of themnamed "Lectern," presumably as a representation of how the human beings exist in this mini-culture only to support the book-flips from page to page, finally conceding that "This isn't what's written" (105). In this moment, the authority of the book is shattered, and neither the book nor its authority ever fully recovers. At the simple level of plot, the book's error forces an enormous detour in the traditional quest fantasy. A quarter of the way into the novel, the hero whom the novel has spent so much time moving into position to begin her quest is shrugged off. It will be another fifty pages before Deeba-whom the prophetic book's index labels "the funny sidekick" (227-28)-returns to Unlondon, at which point she has to spend a tremendous amount of time proving herself to enough other residents simply to gain the allies she needs to begin her quest. Clearly, one of the "structural assumptions" about narrative Miéville challenges is the familiar hero of prophecy whose words and actions are above reproach. A not coincidental victim of Miéville's attack on the heroic structure is the authority of the book that has previously been the subject of such reverence.

If the book's capacity for error is a problem for the heroic prophecy and the group of elites whose role in society is justified by the book's evaporating authority, the book's error is an even bigger problem for the traditional, passive relationship between reader and novel. By entering the discourse of adolescent literature, Miéville is entering a history fraught with books in whom readers are asked to trust; doing so would ensure the "civilizing" process of which Zipes speaks and the circular production of subjects via ideological state apparatuses. 
But by imagining a plot whose crucial turning point is the fact that books are unreliable, Miéville introduces a dissonant voice to that discourse. What Un Lun Dun suggests, particularly in the first scenes, is that books cannot be trusted, upsetting the easy authority of books and denying the comfortable, passive sort of reading that Marxists and children's literature scholars denounce.

In an interview with Joan Gordon, Miéville says that he frequently tries to "undercut narrative security" in his stories, meaning that "you might have to engage in a slightly unexpected way with the text. . . that encourages a kind of engaged and critical reading" ("Reveling" 373). Obviously, this is exactly the kind of renegotiation of reader-text relationship for which children's literature scholarship has been searching, and the novel demonstrates this clearly in the relationship between Deeba and the flawed book. To Deeba and her friend, the book and Propheseers initially represent "home" and "the truth" (82), but when the prophesied hero falls, Deeba denounces the book (106). The book's failings provide a fictionalized model of what it means for narrative security to be undercut, and Deeba's subsequent relationship with the book also models what Miéville says is his goal for readers. Deeba begins to search outside the book's pages for information, which she finds on a piece of paper in the Wraithtown quarter of Unlondon (178), and then returns to the Propheseers with her evidence. She later argues with the book over who can play the role of hero (226), disputes what tasks need to be accomplished in order to defeat the Smog (274), and corrects the book's interpretation of one of its own most important passages (404). The novel's plot and happy ending are enabled because Deeba dares to have these arguments and earns better information as a result of them: she determines that she and her friends can take over the role of hero, that the rather silly and circuitous path the book describes for the hero can be truncated to a single task that will leave time for Deeba to accomplish her own goals, and that she knows better than the book how best to use Unlondon's most storied weapon. The shattering of her faith in the book leads directly to her "engaged and critical reading," which in turn earns Deeba her success.

The novel therefore models the kind of reading that Miéville, Marxist thought, and children's literature scholars interested in a leftist literature for children all privilege. Deeba forms her subjectivity in negotiation with the book rather than in obedience to it: she negotiates her way out of the cliché role of funny sidekick and into a role of her own design. Because she cannot passively trust the book, she is forced out of her comfortable relationship with it, which further forces her to engage with it in ways that succeed where a simple adherence to the words of the book would have failed. But there are two more ways in which Miéville addresses the relationship between reading and subjectivity. In the example of Deeba, Miéville fulfills a promise of leftist 
children's literature, but in the next two examples, he extends the logic of literate subjectivity to include not just readers, but, bizarrely, language and books themselves.

\section{Subjectivity and Language}

As my reading of Althusser has demonstrated, reading can produce subjectivity. In a bourgeois aesthetic, that subjectivity is unified and passive. Leftist literature, however, still requires a reading relationship that produces subjectivity, but it will be a subjectivity that is at least dialectical (in constant, skeptical conversation with the conditions of its production) and perhaps even fractured. Miéville's novel takes this process one step further and in so doing proposes another production of subjectivity tied to language.

In at least two crucial scenes, Un Lun Dun argues a question about language that Lewis Carroll made familiar in children's literature: whether words or speakers are the master. After Deeba has returned to Unlondon, she and her companions are captured by the monstrous Mr. Speaker, whose every word becomes a new creature. Mr. Speaker refuses to allow anyone else to talk, sure that everyone is jealous of his "utterlings." He commands the creatures to take the companions into custody and strikes a bargain with Deeba: if she will teach him new words, he will let the party go. But after Deeba has taught him words from London, he changes his mind, insisting that she remain forever to teach him more and more words. Mr. Speaker's mastery of language binds Deeba and friends in place, and the quest seems to have come to a terrible conclusion.

But it is at this point that Deeba eliminates the mastery of speaker over words. Importantly, she does not precisely take mastery over language herself. Rather, she lays bare the fact that language was never, in fact, controlled by Mr. Speaker. "I don't think," she says, "words do what anyone tells them all the time" (244). She clarifies her point, and the utterlings become increasingly interested in what she is saying: 'Like. . . if someone shouts 'Hey you!' at someone in the street, but someone else turns around. The words misbehaved. They didn't call the person they were meant to" (245). The realization that words do not have to obey, that their subjectivity is not predicated on their enslavement to the desires of the speaker, has a dramatic impact. Within moments, despite Mr. Speaker's outraged protests, "His obedient utterlings had scattered. His words had revolted" (246). With their newly earned freedom, some of the utterlings join Deeba on her quest. In a later scene about a duel with powerful wizards, the rebel utterlings intercept the (this time, bodiless) words of the wizards's spell. They do so not through force but by explaining to the words-in-flight that they do not have to obey the wishes of their casters. Deeba, amazed, realizes that now that the spell-words are aware of their choices, they are unlikely to 
take up the task of hurting Deeba ever again because doing so would mean they complete their purpose and dissipate. "If they do what they were supposed to, then they're finished," Deeba reasons. "I suppose the last thing they want to do now is what they were told. Then they'd be done" (374).

In these two scenes, Miéville gives an explicit nod to Althusser, who used the now-famous example of a man being called with a simple "Hey, you there!" Althusser explains,

Assuming that the theoretical scene I have imagined takes place in the street, the hailed individual will turn round. By this mere one-hundred-and-eighty-degree physical conversion, he becomes a subject. Why? Because he has recognized that the hail was "really" addressed to him, and that "it was really him who was hailed" (and not someone else). Experience shows that the practical telecommunication of hailings is such that they hardly ever miss their man: verbal call or whistle, the one hailed always recognizes that it is really him who is being hailed. (174).

Althusser therefore argues that language, which will be unerring in its mission to address the person targeted by the speaker, produces subjectivity for the person receiving its call in a way similar to the way that reading produces subjectivity. Language is reliable in its interpellation of the target, and the successful recognition of language's meaning in Althusser's example heralds a moment in which a person becomes a subject. Having recognized that the language was meant for him, the man becomes the subject who was the target of the language. Again, Althusser's point is fundamentally pessimistic: by becoming a subject in the terms dictated by the one who hails, the person hailed inscribes himself in the subject position outlined for him by the pre-existing structures of society, the status quo. In this way, language is a tool for a speaker to master not just language, but the listener.

Deeba, however, says precisely the opposite, and in so doing she reveals another of this novel's important insights on language. In Deeba's scenario, the person in the street - exactly how Althusser described him, though Deeba is careful to avoid gendered pronouns — was missed by the words shouted. Deeba does not argue that the person who should have been called lost subjectivity or that the person who mistakenly turned around somehow stole subjectivity, but that the words themselves "misbehaved." What she suggests, and the rest of the scene bears out this point, is that language does not grant subjectivity in its unerring obedience; language marks its own subjectivity in its disobedience.

The implications of Deeba's revision of Althusser are resounding. First, by denying that the person in the street will be inscribed into the superstructure outlined by the greeting, she denies one of the fundamental ways in which the coercive nature of ideology, according to Althusser, works. Deeba is herself at 
the mercy of Mr. Speaker at the beginning of this scene because his words have successfully corralled her into his presence and ensured that she will remain. At stake is her continuation in the role she has negotiated with the book, the role of hero; Mr. Speaker prefers that she abandon that role to perform for him in perpetuity. Her own liberation is of course at stake, and by arguing with Althusser's model of language and subjectivity, she sets herself and her companions free.

But secondly, and in a move that is rare even in other leftist children's literature, she assigns to language itself a kind of subjectivity that, again, it earns and maintains through its disobedience, its argument with authority. Taken together with the book of prophecy, which rebels against its role in the hands of the Propheseers, the utterlings demonstrate a way in which language itself can have a claim to subjectivity. At first blush, this seems to be not leftist at all, but a liberal humanist vision of books, one that grants a sentimental selfhood to various and sundry; and indeed this comfortable vision of universal empowerment is perhaps confirmed when Deeba notes that the book has inherent rights $(222,230)$. More problematically, such a liberal vision of language also links to a common theme in children's literature: the affection for books that provides a happy, non-critical relationship between them and their readers. ${ }^{7}$ If this is the purpose of language's subjectivity in Un Lun Dun, then the discomfort and critical dialecticism of other scenes is diluted. But granting language subjectivity in Un Lun Dun has a different achievement in the novel. By positing language and books as subjects, the novel proposes that these things have a capacity to be wrong and right, and that we can negotiate with them. Further, also in service of the project of uncomfortable engagement outlined above, the novel encourages a de-centralization of subjectivity: the reader is no longer the only seat of subjectivity. Language and books both now take on subjectivity, stealing the comforting starring role from the bourgeois subject.

By rendering language and books as subjects rather than objects, Miéville both alienates the reader as Brecht might an audience and gives the reader a clear voice against which to argue. By prodding the reader into a clear position that cannot tolerate passive consumption of knowledge, Miéville allows a happy relationship with an empowered language that requires argument. The result is a new range of subjectivities that can complicate the entrance of a child reader into ideology. ${ }^{8}$

\section{Notes}

1. In the field of which I speak, "children's literature" is an umbrella term that covers works for the very young as well as for adolescent and teen readers. I will 
therefore use the terms "children's literature" and "young adult literature" almost interchangeably.

2. See "The Critical Reader in Children's Metafiction," forthcoming in The Lion and the Unicorn.

3. Here I am making a point parallel to Fredric Jameson's observation that the "Jamesian point of view" and the "Flaubertian style indirect libre," among other tools of realist fiction, are "strategic loci for the fully constituted or centered bourgeois subject" (154).

4. Terry Eagleton's observation that literature emerged as a field at the historical moment when religion no longer held the broad appeal necessary to maintain the prevalent ideology, indeed that " English' is constructed as a subject to carry this ideological burden from the Victorian period onwards" (Literary Theory 21) also suggests a history in which reading became the material foundation for ideology.

5. Althusser himself saw the "science" of Marxism, which would aid people in seeing their "real" rather than "imaginary" conditions of existence, as the way to escape the endless reproduction of the same. My reading of Miéville does not rely on the same degree of rigid structuralism as characterized Althusser's thought.

6. Such a revolutionary project sheds light on the title of the novel, which is named for the battle cry - "Un Lun Dun!"- of the people who join Deeba's quest, not the name of the city Unlondon. Therefore, the novel is titled after a cry of revolution, not a place.

7. See also Amy Pattee's recent article on the romantic feeling readers tend to have for books and the conflict between that sentimentality and the realities of the production of literature.

8. The author gratefully acknowledges the help of Sherryl Vint and Mark Bould in researching this article.

\section{Works Cited}

Althusser, Louis. "Ideology and Ideological State Apparatuses (Notes toward an Investigation)." 1970. Lenin and Philosophy and Other Essays. Trans. Ben Brewster. New York: Monthly Review Press, 1971. 127-86.

Douglas, Virginie. "Stortytelling and the Adult/Child Relationship in Geraldine McCaughrean's A Pack of Lies, or the Dilemma of Children's Fiction." New Voices in Children's Literature Criticism. Ed. Sebastien Chapleau. Lichfield, Staffordshire: Pied Piper, 2004. 79-87.

Eagleton, Terry. Literary Theory: an Introduction. 2nd ed. Minneapolis: University of Minnesota Press, 1996.

- Marxism and Literary Criticism. Berkeley: University of California Press, 1976.

Grieve, Ann. "Metafictional Play in Children's Fiction." Papers: Explorations into Children's Literature 8.3 (1998). 5-15. 
Jameson, Fredric. The Political Unconscious: Narrative as a Socially Symbolic Act. Ithaca, NY: Cornell University Press, 1981.

Marx, Karl. Grundrisse. 1941. <http://www.marxists.org/archive/marx/works/1857/ grundrisse/ch01.htm>. Accessed 6 Feb 2007.

MacCabe, Colin. Tracking the Signifier: Theoretical Essays: Film, Linguistics, Literature. Minneapolis: University of Minnesota Press, 1985.

Mickenberg, Julia L. Learning from the Left: Children's Literature, the Cold War, and Radical Politics in the United States. Oxford: Oxford UP, 2006.

Mickenberg, Julia L. and Philip Nel, eds. Tales for Little Rebels: a Collection of Radical Children's Literature. New York: New York UP, 2008.

Miéville, China. "China Miéville: Fabular Logic.” Interview. Locus 57.5 (November 2006). 8-9, 73-74.

. "China Miéville: Messing with Fantasy.” Interview. Locus 48.3 (March 2004). 4-5, 75-76.

_. "Reveling in Genre: An Interview with China Miéville." Interview with Joan Gordon. Science Fiction Studies 30.3 (November 2003). 355-73.

_. "Symposium: Marxism and Fantasy. Editorial Introduction." Historical Materialism 10.4 (2002). 39-49.

—. Un Lun Dun. New York: Ballantine Books, 2007.

Moss, Geoff. "Metafiction and the Poetics of Children's Literature." Children's Literature Association Quarterly 15.2 (1990). 50-52.

Pattee, Amy. "Commodities in Literature, Literature as Commodity: a Close Look at the Gossip Girl Series." Children's Literature Association Quarterly 31.2 (Summer 2006). 154-75.

Raskin, Ellen. The Westing Game. 1978. New York: Puffin, 2004.

Sutliff Sanders, Joe. "The Critical Reader in Children's Metafiction." The Lion and the Unicorn. Forthcoming September 2009.

Zipes, Jack. "The Twists and Turns of Radical Children's Literature.” In Mickenberg and Nel. vii-ix. 